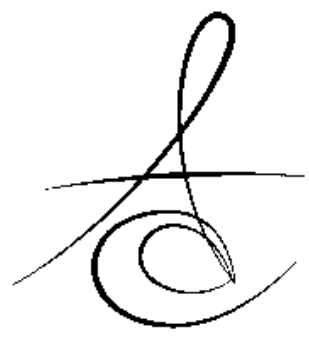

\title{
EOSINOPHILIC GRANULOMA OF THE TEMPORAL BONE MIMICKING TEMPOROMANDIBULAR JOINT DISORDER: REPORT OF A CASE
}

\author{
TEMPOROMANDIBULER EKLEM RAHATSIZLIĞINI TAKLIT EDEN TEMPORAL \\ KEMIĞIN EOZINOFILIK GRANÜLOMASI: VAKA RAPORU
}

\author{
DDS, PhD, Ezher H DAYISOYLU* \\ DMD İlker ÇÖVEN ${ }^{* * *}$
}

\author{
DDS, PhD, Burcu OKTAY ÇÖVEN** \\ DMD, Hilal Özgür ERİNANÇ
}

\author{
Makale Kodu/Article code: 2212 \\ Makale Gönderilme tarihi: 26.03.2015 \\ Kabul Tarihi: 11.05.2015
}

\section{ABSTRACT}

Eosinophilic granuloma (EG) is a rare and relatively benign form of histiocytosis of the Langerhans cells. Radiologically EG characterized by unifocal or multifocal osteolytic lesions that affect the skull. Although the lesion is initially silent, it may erode the bone and destroy the cranial skeleton. Its occurrence on temporal bone indirectly affects the temporalis muscle. In this case report it was aimed to present a patient with EG of temporal bone that mimicking temporomandibular joint disorder (TMD).

Key words: Langerhans Cell Histiocytosis, Eosinophilic Granuloma, Bone lesion, Temporomandibular Joint Disorder

\section{öz}

Eozinofilik Granuloma (EG) Langerhans hücreli histiyositozisin nadir ve göreceli olarak benign formudur. EG Radyografik olarak tek ya da çok odaklı, kafatasını etkileyen ostelitik lezyonlar ile karakterizedir. Lezyon başlangıçta sessiz olmasına karşın kemiği erode ederek kraniyal iskeleti tahrip edebilir. Temporal kemikte görülmesi durumunda temporal kas dolaylı olarak etkilenir. Bu vaka raporunda bir hastada temporomandibuler eklem rahatsızlığını taklit eden temporal kemikteki EG'nin sunulması amaçlandı.

Anahtar Kelimeler: Langerhans Hücreli Histiyositozis, Eozinofilik Granüloma, Kemik Lezyonu, Temporomandibuler eklem problemi

\section{INTRODUCTION}

Langerhan's cell histiocytosis ( $\mathrm{LCH}$ ) is a rare, proliferative disorder in which the accumulation of pathologic Langerhans' cells leads to local tissue infiltration and destruction ${ }^{1}$. Langerhans cells are macrophages that are normally present only in the dermis and the abnormal polyclonal cell proliferation of these cells on bone tissue leads to destruction. LCH has three different variants that are Eosinophilic granuloma (EG), Hand-Schuller-Christian (HSC) and Letterer-Siewe (LS) diseases. EG, also termed as chronic focal $\mathrm{LCH}$, defines solitary or multiple bone lesions without any skeletal involvement. HSC, also termed as chronic disseminated $\mathrm{LCH}$, has specific triad consisting of lytic bone lesions, exophtalmus and diabetes insipidus. On the other hand LS (acute disseminated $\mathrm{LCH}$ ) is a malignant form of $\mathrm{LCH}^{2,3}$ Eosinophilic granuloma (EG) is a rare and relatively benign form of histiocytosis of the Langerhans cells. EG accounts for up to $55-60 \%$ of all cases of $\mathrm{LCH}$. The prognosis of EG is better than the LS and HSC diseases with $90 \%$ survival rate in which spontaneous resolution of solitary or multiple lytic bone lesions may also be seen in $\mathrm{EG}^{4}$. Radiologically EG is found an oval osteolytic lesion about 1-4 cm diameter and the lesion tend to have sharp borders with a punched-out appearance $^{5}$. Development of EG is claimed to be in relation with infection, inflammation or immunologic response, but the cause and pathogenesis of EG is still unclear. There is no widely accepted treatment option for the management of EG, therefore surgery, radiotherapy, chemotherapy or combination of these

\footnotetext{
*Associate Professor Dr, Baskent University, Faculty of Dentistry, Department of Oral and Maxillofacial Surgery

** Consultant, Baskent University, Faculty of Dentistry, Department of Orthodontics

*** Baskent University, Konya Research Hospital, Department of Neurosurgery

${ }^{* * * *}$ Baskent University, Konya Research Hospital, Department of Pathology
} 
Atatürk Üniv. Diş Hek. Fak. Derg.

J Dent Fac Atatürk Uni

Cilt:26, Sayı:1, Yıl: 2016, Sayfa: 129-132
DAYISOYLU, OKTAY ÇÖVEN, ÇÖVEN, ERİNANÇ modalities is reported in the literature with different success rates. Recurrence of EG is infrequently reported but close follow up is essential ${ }^{6}$. EG is more commonly found in males than females with no hereditary, familial or racial predominance. It usually occurs in children but also may be seen in adults and flat bones such as ribs, pelvis and scapula are frequently reported sites for $\mathrm{EG}^{7}$. Localized pain with a palpable tender mass is reported as the chief clinical symptom of EG. On the other hand toothache, headache and sensory disturbances are reported to the other clinical symptoms. EG may be misdiagnosed as temporomandibular joint pain when encountered in the temporal region of the skull. Restriction of mouth opening due to referred pain may also cause misdiagnosis of EG with temporomandibular joint pain. Although EG can be found in the temporal bone, its occurrence in mandible is extremely rare, only 14 cases were reported in the literature ${ }^{8}$. EG of the mandibular condyle is reported to mimic temporomandibular joint (TMJ) pain, on the other hand only one case was found in the literature with EG of the temporal bone mimicking TMJ pain ${ }^{9}$. In this case report a-17-year old male with EG of the temporal bone mimicking TMJ pain was presented.

\section{CASE REPORT}

A-17-year-old male patient was referred to the Department of Oral and Maxillofacial Surgery for the evaluation of ongoing left sided jaw pain for 2 months from his orthodontist. Patient dental and family history was unremarkable. Clinical examination revealed pain and limitation of jaw movement with left sided deviation of the mandible. MMO was noted as $35 \mathrm{~mm}$ and left and right lateral movements were noted as 8 $\mathrm{mm}$ and $6 \mathrm{~mm}$, respectively. Extraoral examination revealed convex facial profile and masticatory muscles were found tender on palpation. In addition postauricular lymphadenopathy and a painfull mass were noted around the temporalis muscle were noted. MRI examination revealed chronic lymphadenopathy with disc displacement. On the other hand a- $25 \times 15 \mathrm{~mm}$ hypodens lesion in relation to temporalis muscle was noted, therefore patient consultated to the Neurosurgery department. Computerized tomography of the temporal bone showed an osteolytic defect of the temporal bone filled with soft tissue (Fig 1).
Patient was operated under general anesthesia and the lesion was totally excised from the temporal bone with its $1 \mathrm{~cm}$ margin. Following total excision of the mass duraplasty was performed with a $15 \times 15 \mathrm{~mm}$ artificial dura material (Duraform ${ }^{\circledR}$, Depuy Synthes, MA, USA) and cortical plate was formed and repaired with polymethymetacrilate (PMMA) resin material (Mendec Spine, Verona, Italy) and closed layer by layer. Histopathological examination revealed that bone marrow of temporal bone was infiltrated with collection of histiocytes with associated eosinophils, lymphocytes, plasma cells and polymorphonuclear giant cells (Fig 2). Immunohistochemical analysis revealed CD68 highlighted numerous macrophages and Langerhans' cells that were also labeled with S100 and CD1a (Fig 3). Immunohistochemical features and morphology were consistent with EG. No complications were noted following the operation and patient is still under follow up with no recurrence for 1 -year.

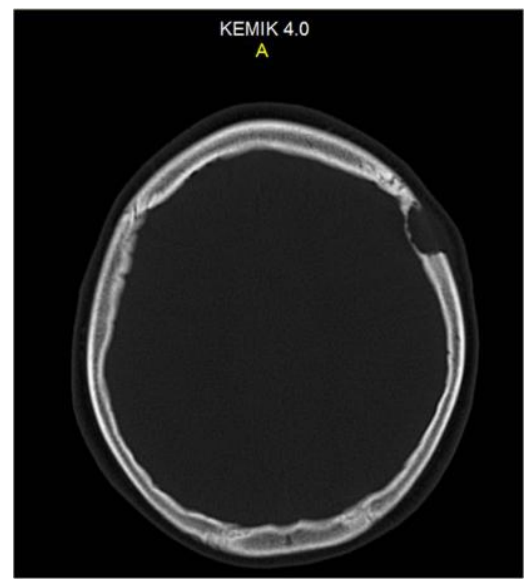

Fig 1. Computed tomography view of the patient. Note the cortical destruction and soft tissue expansion with erosion of the inner table of the temporal bone.

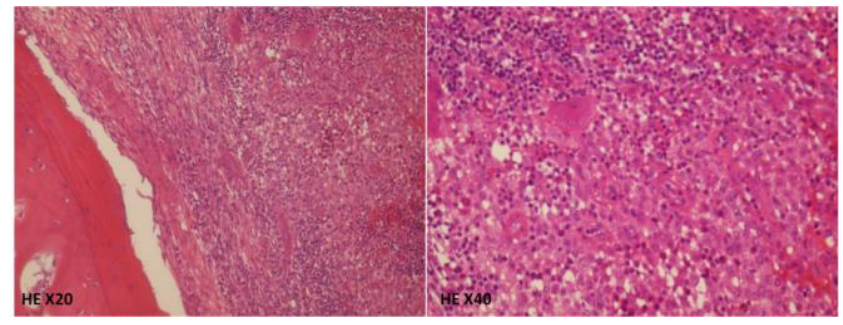

Fig 2. The marrow spaces contain a mixture of histiocytes, lymphocytes, plasma cells, eosinophils and giant cells HEx20 (left) and HEx40 (right)

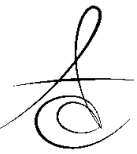


Atatürk Üniv. Diş Hek. Fak. Derg.

J Dent Fac Atatürk Uni

Cilt:26, Sayı:1, Yıl: 2016, Sayfa: 129-132

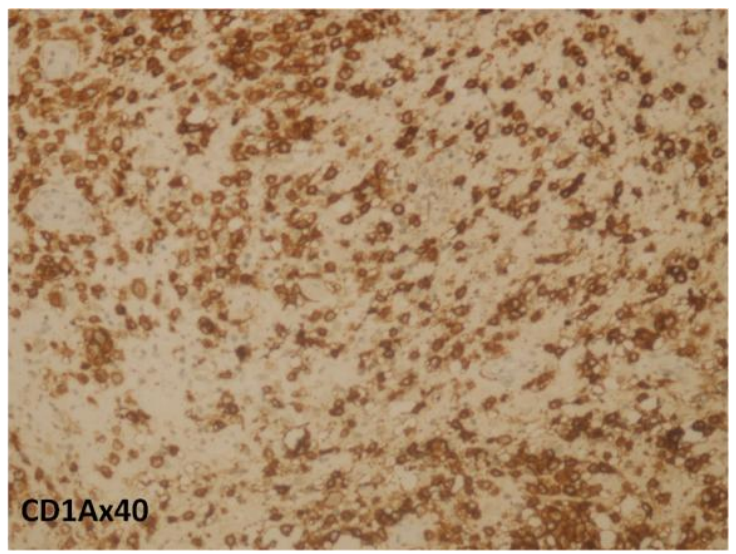

Fig 3. CD1a immunohistochemical stain highlighting of the Langerhans' cells (CD1aX40)

\section{DISCUSSION}

Langerhans cells are antigen presenting cells that have been found in peripheral tissues, such as skin, vaginal mucosa, buccal mucosa, trachea, thymus, blood vessels and lymph nodes. $\mathrm{LCH}$ is characterized abnormal proliferation of Langerhans cells with a granular infiltration. Although epidermal Langerhans cells has been presumed to be the cell of origin in $\mathrm{LCH}$, recent studies showed that other cell groups including dermal langerin ${ }^{+}$cells, lymphoid tissue-resident langerin ${ }^{+}$dendritic cells and monocytes coud have been induced by local environmental stimuli to acquire LCH phenotype ${ }^{10,11}$. Eosinophilic granuloma (EG), Hand- Schuller- Christian disease (HSC) and Letterer- Siwe (LS) diseases are subgroups of LCH. EG most commonly occurs in the long bones of the skeleton such as femur, ribs, vertebrae and EG of the craniomaxillofacial bones are quietly rare. Temporal bone is the most common site for EG that followed by mandible in this region. Radiological findings of EG of the long bones are well documented but radiological features EG of the skull vary considerably. David et al. noted a round to oval osteolytic lesion could be found, on the other hand Ardekian et al. claimed that the lesion might be mistaken for other jaw lesions ${ }^{5,12}$. Ardekian et al. noted orofacial pain was the most common finding in patients with EG that was consistent with our case ${ }^{12}$. In addition sensory disturbances, facial asymmetry and limitation of mouth opening are also described in the literature. Although sensorineural hearing loss is reported one of
DAYISOYLU, OKTAY ÇÖVEN, ÇÖVEN, ERİNANÇ

the common complication of EG, limitation of mouth opening and jaw pain are rare symptoms of craniomaxillofacial EG and only one case was found in the literature with EG of the temporal bone mimicking TMJ pain. Therefore referring pain of EG may be misdiagnosed as temporomandibular joint pain and radiological examination has critical role on the differential diagnosis. Dalili et al. noted an-8- year old girl with EG of skull base mimicking as TMJ pain that was treated via chemotherapy using vinblastine, as well as steroid therapy with prednisolone ${ }^{7,9}$. Yetiser et al. noted that extent of the disease affects the treatment modality. Although surgery and radiotherapy is indicated for single lesions, chemotherapy is suggested for systemic disease or recurrence after initial surgical intervention?. In our case surgical excision of the lesion was preferred and no recurrence was noted for two-year's follow-up.

In conclusion Eosionophilic granuloma is a benign but locally aggressive lesion that may also mimic temporomandibular joint disorders. Detailed clinical and radiological evaluation is crucial for the diagnosis. Although small lesions can be managed by surgery, multiple lesions tend to recurrence therefore adjuvant chemotherapy and radiotherapy should be kept in mind with close follow-up.

\section{REFERENCES}

1. Bayazit $Y$, Sirikci A, Bayaram M, Kanlikama M, Demir A, Bakir K. Eosinophilic granuloma of the temporal bone. Auris Nasus Larynx 2001; 28: 99102.

2. Hernandez-Juyol M, Boj-Quesada JR, Gallego Melcon S. Oral manifestations of Langerhans cell histiocytosis. Case study of a two-year-old boy. Med Oral Patol Oral Cir Bucal 2003; 8:19-25

3. Pekiner FN, Borahan MO, Ozbayrak S, Alatlı C, Kızılyel G. Oral manifestations of chronic disseminated langerhans cell histiocytosis: a case report MUSBED 2012; 2: 138-42

4. Boston M, Derkay CS. Langerhans' cell histiocytosis of the temporal bone and skull base. Am J Otolaryngol 2002; 23: 246-8.

5. David R, Oria RA, Kumar R, Singleton EB, Lindell MM, Shirkhoda $A$ et al. Radiologic features of eosinophilic granuloma of bone. Am J Roentgenol 1989; 153: 1021-6.

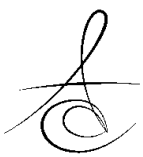


6. Saliba I, Sidani K, El Fata F, Arcand P, Quintal MC, Abela A. Langerhans' cell histiocytosis of the temporal bone in children. Int J Pediatr Otorhinolaryngol. 2008; 72:775-86.

7. Yetiser S, Karahatay S, Deveci S. Eosinophilic granuloma of the bilateral temporal bone. Int J Pediatr Otorhinolaryngol 2002; 62: 169-73.

8. Miyamoto $H$, Dance $G$, Wilson DF, Goss AN. Eosinophilic granuloma of the mandibular condyle. J Oral Maxillofac Surg 2000; 58: 560-2.

9. Dalili $H$, Dalili Kajan Z. Eosinophilic granuloma of the skull base: patient with unique clinical moreover, radiographic presentation. Acta Med Iran 2015; 53: 69-73.

10. Merad M, Ginhoux F, Collin M. Origin, homeostasis and function of Langerhans cells and other langerin-expressing dendritic cells. Nat Rev Immunol 2008; 8: 935-47.

11. Egeler RM, Halteren AG, Hogendoorn PC, Laman JD, Leenen PJ. Langerhans cell histiocytosis: fascinating dynamics of the dendritic cellmacrophage lineage. Immunol Rev 2010; 234: 213-32.

12. Ardekian L, Peled M, Rosen D, Rachmiel A, Abu elNaaj I, Laufer D. Clinical and radiographic features of eosinophilic granuloma in the jaws: review of 41 lesions treated by surgery and low-dose radiotherapy. Oral Surg Oral Med Oral Pathol Oral Radiol Endod. 1999;87:238-42.

\section{Yazışma Adresi}

DDS, PhD, Ezher H DAYISOYLU

Baskent University, Faculty of Dentistry, Department of Oral and Maxillofacial Surgery, Ankara/TURKEY

Tel: +90 5326624778

Fax: +90332 2570632

e-mail: edayisoylu@gmail.com 